\title{
The Educational Potential of Modified Video Games
}

\author{
Andrew Moshirnia \\ University of Kansas, Lawrence, KA, USA
}

Amoshirn@ku.edu

\begin{abstract}
As the popularity of video game playing has increased, educators have sought to co-opt video games as an instructional tool. However, educational games have made little impact in either the commercial market place or the average game player's home library. The modification, or modding, of video games using in-game editors may be used by instructors to introduce educational content to professionally designed video games. This paper examines the effectiveness of a modified video game, Civilization $I V$, in improving the comprehension and retention of historical knowledge of $10^{\text {th }}, 11^{\text {th }}$, and $12^{\text {th }}$ grade students. Students exposed to the modified video game significantly improved their immediate recall of knowledge level history items. Students expressed interest in future educational game playing and felt that they had a better understanding of application level history items. While these results are encouraging, the small sample size of this experiment prevents generalization and necessitates further study.
\end{abstract}

Keywords: Computer-Based Learning, Ludic Learning, Modification

\section{Introduction}

Video game playing has become the preferred form of entertainment for countless children. As the number of home consoles and video game players has grown, so has the interest in gamebased learning. While "educational" video games have been produced, they have sold poorly and made little impact on the home console market. These games are generally perceived to be amateurish and simply not fun to play. If video games are to be used for educational purposes, they must demonstrate the same graphic and game-play characteristics of their commercial peers. Since most games now come bundled with their own game editors, should educators modify the games their students are already playing? Could students benefit from modifying their own games?

The purpose of this paper is to examine the effectiveness of a modified video game in teaching knowledge-level history facts to 10th, 11 th, and 12th grade students. This paper discusses the quantitative and qualitative results of a Solomon-3, time series experiment conducted in 2006 to

Material published as part of this publication, either on-line or in print, is copyrighted by the Informing Science Institute. Permission to make digital or paper copy of part or all of these works for personal or classroom use is granted without fee provided that the copies are not made or distributed for profit or commercial advantage AND that copies 1) bear this notice in full and 2) give the full citation on the first page. It is permissible to abstract these works so long as credit is given. To copy in all other cases or to republish or to post on a server or to redistribute to lists requires specific permission and payment of a fee. Contact Publisher@InformingScience.org to request redistribution permission. assess the educational potential of modified video games.

\section{Previous Research}

This section examines previous research related to the participatory design of educational video games, motivation related to video game creation, constructivism, constructionism, and digital existentialism. 


\section{Definition of Game Modification or Modding}

"A modification to a commercial or user-generated computer game, made by a member of the general public, which may introduce new artifacts (including new items, buildings, and weapons), characters (including enemies and playable characters), models, textures, skins, gaming areas (levels, maps, and buildings), rule sets, and story lines. The finished product may not be sold for profit by its author(s)" (Moshirnia, 2006b, np).

\section{Benefits of Participatory Design}

\section{Higher-order thinking}

An individual must engage in analysis, synthesis, evaluation and revision when she modifies an existing game and creates new objectives (El-Nasr \& Smith, 2006). While creating a working artefact, students can receive continuous feedback from peers and experts (Moshirnia, 2006a). Users establish abstract mental paradigms and develop meta-cognitive skills as they work to optimize functioning designs and to debug flawed designs. Numerous educational researchers, following the creation of the Logo language in the 1960s, have studied the positive ways that programming computers impacts the mathematical, computational, and general thinking skills of the user (Lehrer, 1986; Papert, 1980; Pea, Kurland, \& Hawkins, 1987; Resnick \& Osko, 1993).

\section{Motivation in game design}

Herz (2002) found that the prime motivating factors for individuals who design and modify games are peer acknowledgement and group identity. Both the traditional educational extrinsic need to demonstrate competence and potent intrinsic factors motivate users to modify games (Moshirnia, 2006b). Since game design is traditionally a group project, the sharing of knowledge, skills, and constructive abilities enables group members to feel acknowledged for their individual contributions (Moshirnia, 2006a). At the same time, the finished product is played by non-group members, complimenting the entire design team.

Since the user wants to design something that she finds fun herself, elements of the motivation to play a video game are part of what motivates video game design. Denis (2005) separates ludic motivation into three categories:

- Pleasure-which comes from fantasy, control, power, creation, social interaction, immersion and comedy, direct system response and experience of effectance

- Desire - which comes from curiosity, problem solving and competition, and escapism

- Ludic Tension - which comes from discovery, conflict, suspense and relief, learning, and surprise

Game designers therefore derive motivation both from the game design process and the final product itself (Moshirnia, 2006a).

\section{Constructivist environment}

Game programming creates a constructivist learning environment. Gance (2002) identified four main pedagogical components to constructivism, which are:

- An engaged learner who takes an active role in exploring her environment in order to discover new information.

- A hands-on pedagogy, learn by doing

- A social environment in which learners and mentors interact in a learning context

- A pedagogy that focuses on a realistic problem-solving situation. 
Kafai (1998) noted that students who authored their own games were likely to spend prolonged periods of time creating, evaluating, and revising their designs. This constant self and peer evaluation mandates constructivist discovery learning where learners seek ways to make a game better, test their ideas, discuss their ideas with peers and evaluate whether they have solved the problem (Moshirnia, 2006a).

\section{Constructionism}

Papert (1980), the creator of Logo, used programming as an example of a larger learning theory called constructionism. Constructionism postulates that new knowledge can most effectively be mastered when people engage in constructing products that are personally meaningful. Children will consider their involvement in the creation of a video game to be meaningful since the video game industry now rivals Hollywood in scope (Moshirnia, 2006a). In an attempt to increase undergraduate enrolment in computer science courses, numerous universities have included game design in their curricula. Moskal (2004) found that computer science majors with an emphasis in game creation, when compared with traditional computer science majors, were nearly twice as likely to complete their degree. Constructionism, as expressed through game creation, marries the acquisition of fundamental skills with the personal motivation to learn (Moshirnia, 2006b).

\section{Digital existentialism}

Modders frequently incorporate their belief system, personal preferences, or political opinions in their mods. Hooper (1998) conducted a longitudinal study of software development in schools and concluded that students expressed notions of cultural identity in their programs. Students involved in the design process were able to engage in digital existentialism, creating an electronic version of themselves (Moshirnia, 2006b).

An example of both user agency and digital existentialism is the Chechen Republic Mod produced by Shqype (Moshirnia, 2006a). Made for Civilization IV (in which users lead a civilization to world prominence), the mod creates a previously absent faction, the Chechens. Shqype researched this project while writing his senior thesis on the struggle for Chechen independence. $\mathrm{He}$ introduced a unique unit for the civilization, introduced a script for the name of its cities, e.g. renaming the city of Grozny (which means "frightening" in Russian and is considered offensive to many Chechens), and created a biography for the civilization's leader. Shqype chose to design this mod because he "respect[s] their struggle for independence and viewed [sic] them as an ancient people that deserved recognition (Moshirnia, 2006b, np)."

\section{American Revolution Mod}

The mod used in this experiment was an American Revolution Mod of the game Civilization IV. This is a defined scenario for Civilization $I V$. This section discusses the attributes of this mod type and the different ways it can communicate information to students.

\section{Defined Scenarios}

Defined scenarios may present the greatest educational opportunity in modding, as they place often place the player within a historical struggle (Squire, 2004). In order to create a defined scenario, the modder must, at the very least, create an appropriate map and select the correct AI triggers to ensure that the player has the option of rewriting history. More complex scenarios may require the modder to create previously unplayable factions or modify the artwork associated with an existing faction. Modders must balance the often conflicting desires to create a historically accurate but enjoyable scenario. If the player is placed in a hopeless situation at the onset, repeated failure will not be exciting, no matter how historically accurate the mod may be 
(Moshirnia, 2006b). The creation of scenarios requires a great amount of out-of-game research to allow for the accurate location of troops and cities, and exhaustive in-game beta-testing, to ensure that AI opponents behave appropriately. An example of a successful scenario is the World War I mod for Civilization $I V$. The historically accurate setting presents an ethnically fragmented Austro-Hungarian empire and includes triggers for a late American entry into the war. Scenarios based on WWI and WWII are common, suggesting that a familiarity with subject matter assists scenario creation (Moshirnia, 2006b).

\section{Information Delivery Systems}

The American Revolution Mod uses several different game elements to communicate information to the user. This section reviews these various game elements, indicates how these game elements may be used by future educational mods, and ties each method to a question on the assessment.

\section{Scripted in game events/ pop up window}

The modder may choose to script in game events that occur regardless of the actions of the player. In this particular mod, scripted events, such as the arrival of the French fleet, are accompanied by an informative pop-up window. This feature allows the modder to incorporate a great deal of historical knowledge, which might otherwise be too specific to communicate through other game features. Though this feature has a high capacity for information, it has several disadvantages. The pop only appears once and may be quickly closed by the user (Moshirnia, 2007).

The pop-up must be related to actual gameplay or else the user will have no incentive to actually read the content. Also, the user may complete the game or scenario before a scripted event takes place. The American Revolution mod uses pop-ups to communicate both historical information and to explain new units and diplomacy as they are introduced in the game. This dual functionality keeps users interested in the content of the pop ups. While this feature allows for the greatest range of content, one would expect it to be the least powerful feature in the mod. Figure 1 shows a pop-up announcing the creation of a Colonial Navy in the American Revolution Mod of Civilization IV. The text details an in game event and presents learners with the opportunity to better understand the cause and effect of the event.

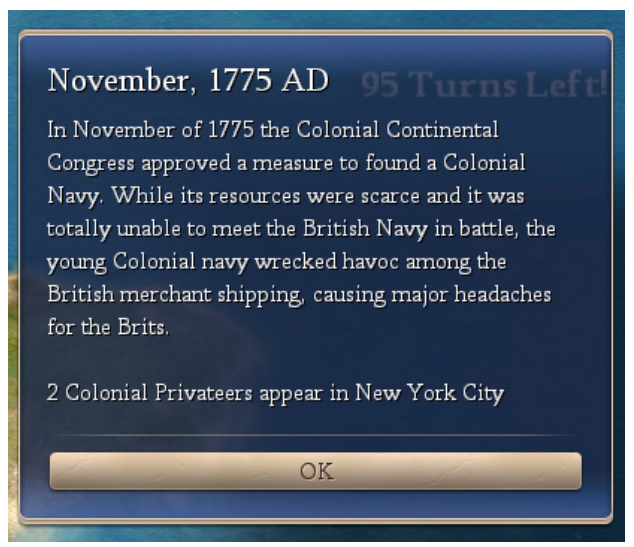

Figure 1: An informational pop-up in the American Revolution Mod of Civilization IV

\section{Continuous on screen in game information - geography, score boards}

The modder may also communicate information through continuous, in game elements. The geography of an in-game map is a good example of this feature, as users must repeatedly reference the map to successfully complete the scenario (Moshirnia, 2007). This tool may be used to communicate lower level knowledge (e.g. students memorize the locations of cities in the United States) but it may also give students the information needed to arrive at more complex conclusions (e.g. a map which includes the railroad systems of the Union and the Confederacy will allow students to infer generalizations regarding the industrial capacity of both belligerents.) Figure 2 shows Colonial forces surrounding the city of Boston. Students might learn or better understand several facts by examining this situation. These include: Boston was the major battle ground in 


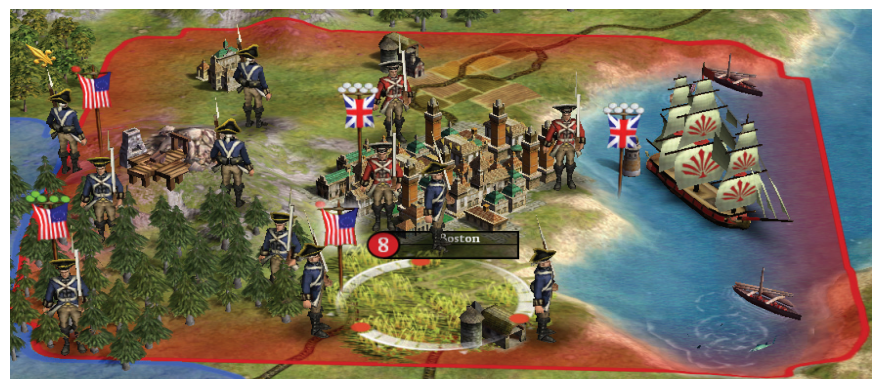

Figure 2: An example of geography information in the American Revolution Mod of Civilization IV

the Northern Theater, Boston is port, Boston was exposed to the British Navy, and British forces tended to remain in cities while Colonials controlled outlying areas. Figure 3 shows the score and diplomacy feature of Civilization IV. Players may assess the relative strength of all forces in the game by looking at the continuous score display in the lower right hand corner of the screen. This menu is also used to conduct diplomacy with opponents. The leader of each faction is listed next to score of his or her civilization. In this case, students may learn the names of the leaders of the British, French, and Spanish empires at the time of the revolutionary war.

The assessment asks students to identify the city which was the center of the early northern campaign (Boston) and the city used by the British as a Royal Navy base (Halifax). Neither piece of information is

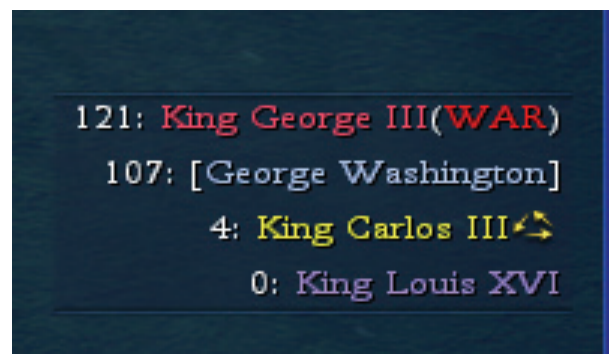

Figure 3: The diplomacy menu in the American Revolution Mod of Civilization IV directly stated in the mod.

\section{Sprites}

Information may be communicated by the appearance, attributes, and labels given to an in-game sprite. Figure 4 shows that in this mod, for example, a student may learn the name of American infantry (minutemen), their garb, the weapons they used, and their strength relative to British Infantry. Sprites are a powerful information delivery device because users must become familiar with a unit's attributes in order to successfully use that unit. However, since there are a wide variety of units in the game, the user may not be exposed to the information regarding every unit (Moshirnia, 2007). The assessment asked two questions which may be answered from unit information regarding German Mercenaries and Minutemen.

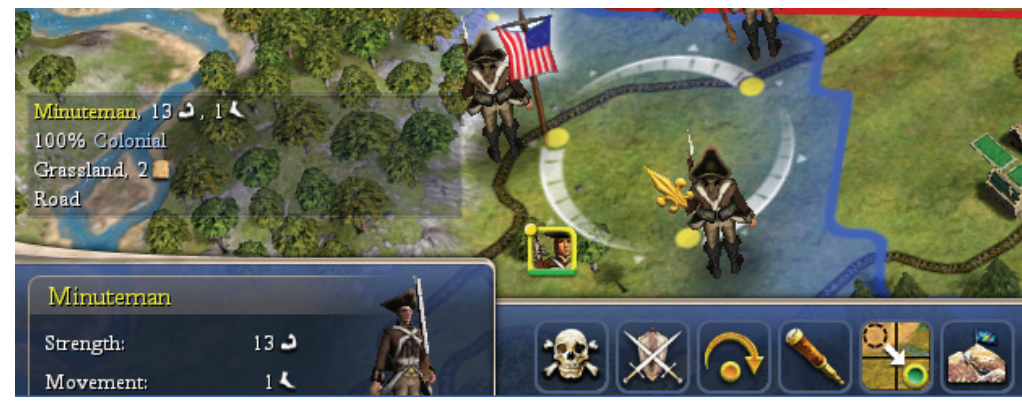

Figure 4: Minuteman sprite information in the American Revolution Mod of Civilization IV 


\section{In game guides, instruction manuals}

A great deal of information may be contained within the in-game guide or instruction manual. The game Civilization IV has a detailed in-game guide called the Civopedia, which may be used by modders to explain changes to the game's rule set. Due to time constraints, this feature was not used in this experiment. Figure 5 shows the Civopedia entry regarding Louis XVI, the king of France during the revolutionary war. The entry includes basic biographical information, including the dates of Louis XVI's reign and his foreign policy.

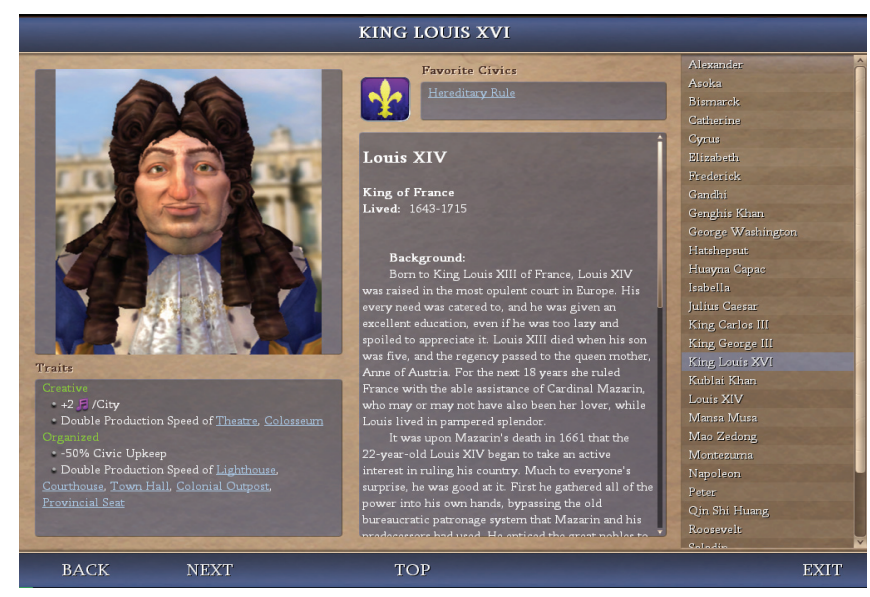

Figure 5: The Civopedia entry for Louis XVI in the Revolution Mod of Civilization IV

\section{Experiment}

\section{Overview}

\section{Design}

This experiment utilized a Solomon-3, time series, between-subjects design. Subjects $(N=6)$ were randomly assigned to 3 treatment groups $(n=2)$, post test only lecture (Control-2), pre-test post-test lecture, (Control-1) and pre-test post-test game (Experimental).

\section{Population}

6 Caucasian students in the $10^{\text {th }}, 11^{\text {th }}$, and $12^{\text {th }}$ grades, comprised of an equal number of males and females $(n=3)$ volunteered to learn an extra unit of American History. There are $312^{\text {th }}$ graders and $110^{\text {th }}$ grader in the control groups and $211^{\text {th }}$ graders in the treatment group. Recruitment of subjects was ineffective, as the number of volunteers fell well below the anticipated 30 . This reduced the power of this pilot and necessitated the design of a second pilot, to be run in April 2007.

\section{Intervention}

Students in the game group were given the opportunity to play the American Revolution mod of the computer game Civilization IV. Students were allowed to play the game for three hours, with the option to take notes in a composition notebook as they played. 


\section{Comparison/Control}

Students within the lecture groups attended a one-hour lecture on the revolutionary war.

\section{Procedure}

Data was collected through the administration of a content-validated, 20 item short answer history exam. Each form of the exam contained the same 20 items. Subjects in the pretest groups took this exam three times: 7 days before the intervention, 1 day after the treatment, and 7 days after the treatment. Subjects in the posttest-only group took this exam 1 day after the treatment and 7 days after the treatment. A week after the intervention, the students were given an unannounced retest. Following this $2^{\text {nd }}$ posttest, qualitative data was gathered from subjects in a journal exercise and semi-structured interview.

Statistical methods were common procedures for evaluating experimental outcomes, for example, t-test and analysis of variance.

\section{Quantitative Results}

\section{Baseline for pretest-posttest groups}

A one-way ANOVA was conducted on the pretests and revealed no significant difference between the pretest-posttest control and experimental groups, as can be seen in Table 1.

Table 1: Comparison of Pretest scores of Experimental and Control-1 groups

\begin{tabular}{|l|l|l|l|l|}
\hline & Mean & $\begin{array}{l}\text { Standard } \\
\text { Devia- } \\
\text { tion }\end{array}$ & $\begin{array}{l}\text { Number } \\
\text { of Sub- } \\
\text { jects }\end{array}$ & $\begin{array}{l}\text { Signifi- } \\
\text { cance }\end{array}$ \\
\hline $\begin{array}{l}\text { Experi- } \\
\text { mental }\end{array}$ & 4.5 & .70711 & 2 & \\
\hline $\begin{array}{l}\text { Control- } \\
1\end{array}$ & 3.5 & .70711 & 2 & .293 \\
\hline
\end{tabular}

\section{No pretest effect}

The immediate posttest scores for the Pretest-Posttest control and the Posttest only control were compared to determine if there was a pretest effect. No significant difference was found, as can be seen in Table 2 .

Table 2: Comparison of Immediate posttest scores for the Control groups, indicating no Pretest effect

\begin{tabular}{|l|l|l|l|l|}
\hline & Mean & $\begin{array}{l}\text { Standard } \\
\text { Devia- } \\
\text { tion }\end{array}$ & $\begin{array}{l}\text { Number } \\
\text { of Sub- } \\
\text { jects }\end{array}$ & $\begin{array}{l}\text { Signifi- } \\
\text { cance }\end{array}$ \\
\hline $\begin{array}{l}\text { Control- } \\
1\end{array}$ & 14.5 & 3.53553 & 2 & \\
\hline $\begin{array}{l}\text { Control- } \\
2\end{array}$ & 16.5 & 2.12132 & 2 & .564 \\
\hline
\end{tabular}

\section{Gains of experimental group}

Since no pretest effect was detected, the observed gains of the Experimental group must have been caused by the intervention. The pretest and posttest scores were compared within the Ex- 
perimenatal group. The gain was significant. Table 3 shows that the mean scores of the experimental group doubled following the treatment. The effect size of the treatment variable was very strong, accounting for $97.6 \%$ of an individual's score.

\section{Table 3: Comparison of Pretest and Immediate Posttest scores} of the Experimental Group

\begin{tabular}{|l|l|l|l|l|}
\hline & Mean & $\begin{array}{l}\text { Standard } \\
\text { Devia- } \\
\text { tion }\end{array}$ & $\begin{array}{l}\text { Number } \\
\text { of Sub- } \\
\text { jects }\end{array}$ & $\begin{array}{l}\text { Signifi- } \\
\text { cance }\end{array}$ \\
\hline $\begin{array}{l}\text { Experi- } \\
\text { mental } \\
\text { Pretest }\end{array}$ & 4.5 & .70711 & 2 & \\
\hline $\begin{array}{l}\text { Experi- } \\
\text { mental } \\
\text { Posttest } \\
1\end{array}$ & 9.0 & 0 & 2 & .012 \\
\hline
\end{tabular}

\section{Loss scores and retention rate}

For all subsequent calculations, Control Groups 1 and 2 were collapsed into a single Control Group as they both received the same treatment and no pretest effect was detected. The delayed posttests were collected from all groups and loss scores were calculated. These scores were compared using a one-way ANOVA. The control group showed a lower retention rate. Tables 4 and 5 show the loss scores and retention rate between the immediate and delayed posttests.

Table 4: Comparison of score decrease from immediate posttest to delayed posttest

\begin{tabular}{|l|l|l|l|l|}
\hline & Mean & $\begin{array}{l}\text { Standard } \\
\text { Devia- } \\
\text { tion }\end{array}$ & $\begin{array}{l}\text { Number } \\
\text { of Sub- } \\
\text { jects }\end{array}$ & Sig \\
\hline $\begin{array}{l}\text { Experi- } \\
\text { mental } \\
\text { Loss }\end{array}$ & 0 & 0 & 2 & \\
\hline $\begin{array}{l}\text { Control } \\
\text { Loss }\end{array}$ & 1.50 & .577 & 4 & .026 \\
\hline
\end{tabular}

Table 5: Comparison of retention rate from immediate posttest to delayed posttest

\begin{tabular}{|l|l|l|l|l|}
\hline & Mean & $\begin{array}{l}\text { Standard } \\
\text { Devia- } \\
\text { tion }\end{array}$ & $\begin{array}{l}\text { Number } \\
\text { of Sub- } \\
\text { jects }\end{array}$ & Sig \\
\hline $\begin{array}{l}\text { Experi- } \\
\text { mental } \\
\text { Renten- } \\
\text { tion\% }\end{array}$ & 1.00 & 0 & 2 & \\
\hline $\begin{array}{l}\text { Control } \\
\text { Reten- } \\
\text { tion\% }\end{array}$ & .90 & .03 & 4 & .013 \\
\hline
\end{tabular}

\section{Information Delivery Scores}

For only the game group, a one-way ANOVA was run on question types to see if students learned more from different information delivery systems within the mod. Questions were sorted into 
three groups based on way the mod provided the relevant information to the player. Questions $1,2,3,4,5,8,10,11,13,15,16,18,19,20(\mathrm{n}=14)$ could be answered based on information presented within in-game pop ups. Questions 6,7,12,17 $(\mathrm{n}=4)$ could be answered based on on-screen events and continuous displays. Questions 9 and $14(\mathrm{n}=2)$ could be answered based on in-game sprites. An omnibus f-test returned a significant difference. Bonferroni and Scheffe post hoc tests showed a significant difference between Sprite Based information and the other two delivery systems. Table 6 shows the experimental groups mean percent score on items coded to different in game delivery systems.

Table 6: Comparison of percent of correct answers for questions based on different in-game delivery systems

\begin{tabular}{|l|l|l|l|l|}
\hline & $\begin{array}{l}\text { Mean } \\
\text { Percent } \\
\text { Score }\end{array}$ & $\begin{array}{l}\text { Standard } \\
\text { Deviation }\end{array}$ & $\begin{array}{l}\text { Number } \\
\text { of Sub- } \\
\text { jects }\end{array}$ & Sig \\
\hline $\begin{array}{l}\text { Pop up } \\
\text { Delivery }\end{array}$ & 37.5 & 17.67767. & 2 & \\
\hline $\begin{array}{l}\text { In game } \\
\text { Delivery }\end{array}$ & 46.5 & 4.94975 & 2 & .018 \\
\hline $\begin{array}{l}\text { Sprite } \\
\text { Delivery }\end{array}$ & 100 & 0 & 2 & \\
\hline
\end{tabular}

\section{Qualitative Results}

\section{Video games better suited for higher-level questions}

The subjects in the game group commented that they felt the game did a better job "teaching things other than dates. I learned concepts but not ... dates since they weren't emphasized in the game. For example, I used to play Zeus and I learned a lot of mythology. I didn't learn from the boxes because they just popped up and went away. I did learn the geography and comparative strengths of the two armies." Students felt that the method of teaching did not match the items on the exam, stating that, "if you had asked different types of questions, I would have done better" One subject remarked that he enjoyed the opportunity to see the war from the British perspective, "I referred to the colonists as rebels on my test."

\section{Video games as compared to lectures}

Students compared learning through video games to the more traditional, lecture method. Students expressed frustration with poorly paced lectures, "I feel like I learned more than just being in a lecture but I would have got more date questions if I was taking notes in a lecture." "I'm always taught by lectures but they're usually boring and inefficient. I like to read textbooks so I can get through the material more quickly."

\section{Increased motivation}

Subjects in the experimental group commented that "I wanted to play more than I wanted to do homework... It was definitely more fun and I learned more than I would have from a bad lecture." "It was hard to only play for 3 hours". This method made the information easier to remember because "the fact that events in history have material implications impacts the learning process ...because it actually makes a difference to the player if, e.g., the Rebels create a navy, or that His Majesty's Royal Army receives reinforcements from German Mercenaries." One subject commented that the extra motivation to study from video games was unnecessary for advanced students. "Maybe this would be a better method for kids who don't have the motivation to study on their own." 


\section{Conclusion}

\section{Interpretation of Results}

Students in the experimental group showed significant growth after being exposed to the modified video game. This growth was not significantly altered by a pretest effect. Students in the experimental group felt that they had learned more than their test results indicated. Test items were knowledge-level items and students in the game group felt that they could attempt higher-order thinking questions. The growth for all groups was significant, but students who received information from lecture showed a significantly lower rate of knowledge retention than students who learned from the mod. This suggests that modified video games could not only improve comprehension, but also retention of knowledge-level items. Students learned more from information that was delivered through sprites. However, the small sample size of this study prevents generalization of results.

Teachers may use the popularity of video games to increase student motivation. Students are not only able to learn from modified video games but are also likely to enjoy the experience more than the traditional lecture method. Modding is a field with great educational promise, for game makers and game players alike. As personal computers and in-game editors grow in strength, users inch closer to the reality of being able to create their own graphically impressive games. By tapping into the appeal of video game playing and a user's natural tendency to place him- or herself "in the game", mods encourage students to experience subject matter. Just as one subject identified with the British army, or "His Majesty's Royal Army", students may feel a greater connection to an interactive, digital history than to the facts they learn in lectures. Perhaps students will be encouraged to learn more about the past if they are allowed to change it.

\section{Questions for Further Study}

The sample size of this study was quite small. Future studies should involve a greater number of more varied subjects. The time-series design could be lengthened to give a fuller view of a modified video game's effects on retention. This study examined only one type of modified video game, the turn-based strategy game. Future studies should examine if other game types, such as First Person Shooter (FPS) or Real Time Strategy (RTS), have a similar effect size.

\section{References}

Denis, G., \& Jouvelot, P. (2005) Motivation-driven educational game design: Applying best practices to music education. $A C E$, E-learn 2005. Retrieved June 1, 2006, from http://www.cri.ensmp.fr/classement/doc/A-365.pdf

El-Nasr, M., \& Smith, B. (2006). Learning through game modding. ACM, Computers in Entertainment, $4(1), 3 b$.

Gance, S. (2002, May) Are constructivism and computer-based learning environments incompatible? Journal of the Association for History and Computing, V(1).

Herz, J. (2002). Gaming the system: What higher education can learn from multiplayer online worlds. The Internet and the University. Retrieved June 6, 2006, from http://www.educause.edu/ir/library/pdf/ffpiu019.pdf

Hooper, P. (1998). They have thoughts of their own: Children's learning of computational ideas from a cultural constructionist perspective. Cambrigde, MA: University Press.

Kafai,Y.B. (1998). Video game designs by girls and boys: Variability and consistency of gender differences. In Cassell \& Jenkins (Eds.), From Barbie to mortal combat: Gender and computer games. Cambridge, MA: MIT Press. 
Lehrer, R. (1986) Logo as a strategy for developing thinking. Educational Psychologist, 21(2), 121-137.

Moshirnia, A. (2006a). The impact of procedural generation and modding on the peer design of educational video games. Proceedings of IASTED: CATE 2006. In print.

Moshirnia, A. (2006b). Knowledge sharing structures within modification culture. Proceedings of IASTED: KSCE 2006. In print.

Moshirnia, A. (2007). An assessment of information delivery systems within modified video games. Proceedings of IATED 2007. In print.

Moskal, B. (2004). Evaluating the effectiveness of a new instructional approach. Proceedings of $25^{\text {th }}$ SIGSCE technical symposium on computer science education. NY: ACM Press, 75-79.

Papert, S. (1980). Midstrorms: Children, computers and powerful ideas. NY: Basic Books.

Pea, R., Kurland, D., \& Hawkins, J. (1987). Logo and the development of thinking skills In S. Papert, Midstrorms: Children, computers and powerful ideas. NY: Basic Books.

Resnick, M., \& Ocko, S. (1993). Lego/logo: Learning through and about design. Norwood, NJ: Ablex books.

Squire, K. (2004). Replaying history: Learning world history through playing Civilization III. Unpublished doctoral dissertation. Indiana University.

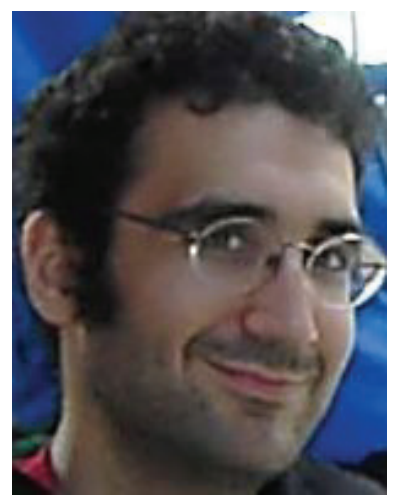

\section{Biography}

Mr. Andrew Moshirnia is pursuing his Doctorate in Educational Technology at the University of Kansas. He is currently working for the E-Learning Design Lab and Lawrence Free State High School. His research interests include ludic motivation, game modification, and the instruction of classical languages. 